\title{
Hubungan Mikroflora Usus pada Bayi Baru Lahir dengan Jenis Persalinan
}

Mira Febriani Hontong, Sarah M Warouw, Jeanette I.Ch. Manoppo, Praevilia Salendu

Bagian SMF Ilmu Kesehatan Anak Fakultas Kedokteran Universitas Sam Ratulangi / RS Prof.Dr.R.D.Kandou, Manado

Latar belakang. Mikroflora saluran cerna pada awal kehidupan berperan penting untuk respon imun dan dapat dipengaruhi oleh jenis persalinan. Tujuan. Mengetahui hubungan antara jumlah koloni mikroflora usus Bifidobacterium, Lactobacillus, Clostridium, pada bayi baru lahir dengan jenis persalinan.

Metode. Penelitian observasional analitik dengan pendekatan potong lintang terhadap semua bayi aterm sehat yang lahir pervaginam dan seksio sesarea dari bulan Oktober 2013-November 2013 di Divisi Perinatologi Departemen Ilmu Kesehatan Anak (IKA) RSUP Prof. Dr. R.D. Kandou, Manado. Dilakukan pemeriksaan tinja dengan quantitative realtime polymerase chain reaction (PCR-RT) untuk mendeteksi kolonisasi mikroflora Bifidobacterium, Lactobacillus, dan Clostridium. Pengolahan data dengan uji Mann-Whitney.

Hasil. Dua puluh lima subjek bayi lahir pervaginam dan 25 subjek bayi lahir secara seksio. Terdapat perbedaan bermakna jumlah koloni Bifidobacterium pada persalinan pervaginam (median 2,19 x $109 \mathrm{CFU} / \mathrm{g}$ ) dibandingkan seksio sesarea (median 1,55 x $109 \mathrm{CFU} / \mathrm{g})(\mathrm{p}<0,001)$. Median koloni Lactobacillus pada persalinan pervaginam 3,40 x 109 CFU/g tidak berbeda bermakna dengan seksio sesarea 3,51 x $109 \mathrm{CFU} / \mathrm{g}(\mathrm{p}=0,362)$. Median koloni Clostridium pada persalinan pervaginam 1,12x $109 \mathrm{CFU} / \mathrm{g}$ juga tidak berbeda bermakna dengan seksio sesarea 1,04 x $109 \mathrm{CFU} / \mathrm{g}$ (p=0,961).

Kesimpulan. Persalinan pervaginam kolonisasi mikroflora Bifidobacterium lebih tinggi dibandingkan dengan seksio sesarea. Tidak terdapat perbedaan bermakna kolonisasi mikroflora Lactobacillus dan Clostridium pada persalinan pervaginam dan seksio sesarea. Sari Pediatri 2015;17(1):25-8.

Kata kunci: bifidobacterium, lactobacillus, clostridium, mikroflora usus

\section{Correlation between Modes of Delivery and Intestinal Microflora in Newborns}

Mira Febriani Hontong, Sarah M Warouw, Jeanette I.Ch. Manoppo, Praevilia Salendu

Background. Intestinal microflora in the early life plays an important role in the immune response and may be influenced by modes of delivery.

Objectives. To identify the correlation between modes of delivery and the number of Bifidobacterium, Lactobacillus, and Clostridium colonies in newborns.

Methods. An analytical observational study with cross-sectional approach on healthy term infants born through vaginal delivery and Caesarian section from October 2013 to November 2013 in the Perinatology Division, Pediatrics Department of Prof Dr. R. D. Kandou General Hospital. Fecal analysis with quantitative real-time polymerase chain reaction (PCR-RT) was performed to detect the colonization of Bifidobacterium, Lactobacillus, and Clostridium microflora. Data was analyzed using Mann-Whitney test.

Results. Twenty five vaginally born infant and 25 Caesarian born infants. We found a significant difference between the number of Bifidobacterium colonies on infants born through vaginal delivery (median $2.19 \times 109 \mathrm{CFU} / \mathrm{g}$ ) and the number of colonies in infants born through Caesarian section (median $1.55 \times 109$ CFU/g) $(\mathrm{p}<0.001)$. The median of Lactobacillus colony in infants born through vaginal delivery was $3.40 \times 109 \mathrm{CFU} / \mathrm{g}$, and was not significantly different with that of infants born through Caesarian section (3.51 $\mathrm{x} 109 \mathrm{CFU} / \mathrm{g})(\mathrm{p}=0.362)$. The median of Clostridium in infants born through vaginal delivery was $1.12 \times 109 \mathrm{CFU} / \mathrm{g}$ and this was also not significantly different with that of infants born through Caesarian section (median 1.04 x 109 CFU/g) (p=0.961).

Conclusion. The colonization of Bifidobacterium microflora in infants born through vaginal delivery is significantly higher than that of infants born through Caesarian section. There were no significant differences between the colonization of Lactobacillus and Clostridium microflora in both infants born through vaginal delivery and infants born through Caesarian section. Sari Pediatri 2015;17(1):25-8.

Keywords: bifidobacterium, Lactobacillus, Clostridium, intestinal microflora,

Alamat korespondensi: Dr. Mira Febriani Hontong, Sp.A. Bagian SMF Ilmu Kesehatan Anak Fakultas Kedokteran Universitas Sam Ratulangi / RS Prof.Dr.R.D.Kandou, Manado. E-mail: mirainkiriwang@idai.or.id, mirainkiriwang@gmail.com 
$\mathrm{B}$ akteri yang paling penting dan menguntungkan untuk manusia adalah Bifidobacterium dan Lactobacilus, sedangkan bakteri Clostridium merupakan bakteri yang potensial patogenik. ${ }^{1}$ Bifidobacterium dan Lactobacilus merupakan elemen penting pada flora usus sebagai salah satu bakteri anaerob yang dominan di usus. Beberapa penelitian telah melaporkan bahwa mikroflora saluran cerna pada awal kehidupan berperan penting untuk respon imun, tetapi mikroflora saluran cerna dipengaruhi juga oleh seksio sesarea yang dapat mengubah atau menyebabkan keterlambatan kolonisasi flora usus pada bayi. Perubahan ini dipengaruhi oleh banyak faktor. ${ }^{2-4}$

Kolonisasi bakteri usus akan mengalami keterlambatan pada bayi yang lahir secara seksio sesarea. Bayi yang lahir secara seksio sesarea ditandai oleh rendahnya koloni Bacteroides, Bifidobacterium, dan Lactobacillus. ${ }^{3}$ Jenis persalinan mempunyai dampak signifikan pada pembentukan mikrobiota saluran cerna. Bayi yang lahir secara pervaginam akan dikolonisasi pertama kali oleh bakteri yang berasal dari fekal dan vaginal ibu, sedangkan bayi yang lahir melalui seksio sesarea akan dikolonisasi oleh bakteri yang berasal dari lingkungan rumah sakit dan petugas kesehatan. ${ }^{4}$ Selanjutnya, keterlambatan kolonisasi usus pada bayi yang lahir secara seksio sesarea dikarakterisasi oleh rendahnya jumlah koloni Bifidobacterium, Laktobacidus, dan Bakteriodes. dibandingkan dengan persalinan pervaginam..$^{5-10}$

Tujuan penelitian ini adalah untuk mengetahui hubungan jumlah koloni mikroflora usus antara lain Bifidobacterium, Lactobacilus, dan Clostridium pada bayi baru lahir dengan jenis persalinan pervaginam dan seksio sesarea.

\section{Metode}

Penelitian ini menggunakan metode observasional analitik dengan pendekatan potong lintang. Penelitian dilakukan di Divisi Perinatologi Departemen Ilmu Kesehatan Anak (IKA) RSUP Prof.Dr.R.D. Kandou, Manado dari bulan Oktober 2013 sampai dengan November 2013.

Sampel penelitian diambil secara consecutive sampling. Kriteria inklusi adalah bayi aterm yang lahir pervaginam dan seksio sesarea, bayi sehat, dan orang tua setuju untuk ikut serta dengan menandatangani formulir persetujuan. Kriteria eksklusi adalah bayi dengan kelainan bawaan, bayi baru lahir dengan APGAR skor pada menit ke-5 kurang dari 7, dan dirawat di NICU. Terdapat dua jenis variable, yaitu jenis persalinan yang terdiri dari pervaginam dan seksio sesarea sebagai variabel bebas dan jumlah koloni Bifidobacterium, Lactobasilus, dan Clostridium sebagai variabel tergantung.

Data dikumpulkan dari anamnesis, pemeriksaan fisik, dan pemeriksaan laboratorium. Spesimen tinja bayi diambil pada hari pertama lahir, diambil \pm 1 gram, kemudian dimasukkan ke dalam botol steril menggunakan sendok steril, selanjutnya dikirim ke laboratorium untuk dilakukan pemeriksaan. Penentuan jumlah koloni Bifidobacterium, Lactobacillus, dan Clostridium pada tinja menggunakan teknik deteksi DNA dari bakteri melalui pemeriksaan Quantitative real-time polymerase chain reaction (PCR-RT).

Data disajikan dalam bentuk rerata, simpang baku (SB), median, dan rentang. Kolonisasi mikroflora Bifidobacterium, Lactobacillus, dan Clostridium pada persalinan pervaginam dan seksio sesarea dibandingkan dengan menggunakan uji Mann-Whitney karena data tidak menyebar normal. Data diolah dengan menggunakan program SPSS versi 22. Nilai signifikansi yang digunakan adalah $\mathrm{p} \leq 0,05$. Penelitian ini telah mendapat persetujuan dari Komite Etik Penelitian Fakultas Kedokteran Universitas Sam Ratulangi.

\section{Hasil}

Selama kurun waktu penelitian didapatkan 25 bayi lahir pervaginam dan 25 bayi yang lahir secara seksio sesarea yang memenuhi kriteria inklusi. Terdapat $29(58 \%)$ bayi lelaki, 15 (52\%) lahir secara pervaginam, dan 14 (48\%) lahir secara seksio sesarea. Terdapat bayi perempuan 21 (42\%), lahir secara pervaginam 10 (48\%) dan 11 (52\%) secara seksio sesarea.

Pada persalinan pervaginam maupun seksio sesarea, koloni mikroflora usus bayi baru lahir terbanyak adalah Lactobacillus diikuti Bifidobacterium, Clostridium.

Terdapat perbedaan bermakna jumlah koloni Bifidobacterium pada persalinan pervaginam (median $2,19 \times 10^{9} \mathrm{CFU} / \mathrm{g}$, dibandingkan seksio sesarea (median 1,55x 10 $0^{9} \mathrm{CFU} / \mathrm{g},(\mathrm{p}<0,001)$. Median koloni Lactobacillus pada persalinan pervaginam 3,40x $10^{9}$ $\mathrm{CFU} / \mathrm{g}$ tidak berbeda bermakna dengan median seksio sesarea 3,51 x 109 CFU/g ( $\mathrm{p}=0,362)$. Median 
Mira Febriani Hontong dkk: Hubungan mikroflora usus pada bayi baru lahir dengan jenis persalinan

Tabel 1. Pengujian perbedaan jumlah koloni(x $\left.10^{9} \mathrm{CFU} / \mathrm{g}\right)$ pada persalinan pervaginam dan seksio sesarea

\begin{tabular}{llccc}
\hline Kolonisasi & Jenis persalinan & Median & Rentang & $\mathrm{p}$ \\
\hline Bifidocterium & Pervaginam & 2,19 & $1,5-2,98$ & \\
& Seksio sesarea & 1,55 & $0,81-2,54$ & $<0,001$ \\
Lactobacillus & Pervaginam & 3,40 & $0,97-4,05$ & \\
& Seksio sesarea & 3,51 & $2,30-3,88$ & 0,362 \\
Clostridium & Pervaginam & 1,12 & $0,75-1,71$ & \\
& Seksio sesarea & 1,04 & $0,73-3,39$ & 0,961 \\
\hline
\end{tabular}

koloni Clostridium pada persalinan pervaginam 1,12 juga tidak berbeda bermakna dengan median seksio sesarea $1,04 \times 10^{9} \mathrm{CFU} / \mathrm{g}(\mathrm{p}=0,961)$. Hasil pengujian perbedaan jumlah koloni mikroflora usus pada jenis persalinan tertera pada Tabel 1.

\section{Pembahasan}

Penelitian ini mengambil sampel bayi baru lahir pada hari pertama karena kolonisasi bakteri terjadi segera setelah lahir. Dominguez-Bello dkk ${ }^{11}$ melaporkan bahwa pada sampel feses mekonium usia $<24$ jam pada bayi yang lahir pervaginam, ditemukan adanya komunitas bakteri yang mirip dengan bakteri vaginal ibunya, yaitu Lactotobacillus dan Bifidobacterium. Yoshioka $\mathrm{dkk}^{12}$ menemukan Bifidobacterium pada hari pertama kelahiran $10^{5} \mathrm{CFU} / \mathrm{g}$ feses.

Kolonisasi adalah proses bertahap yang ditentukan oleh banyak factor, antara lain komposisi mikroflora usus ibu, lingkungan, derajat kebersihan, jenis persalinan, pemakaian antibiotik, dan perawatan di rumah sakit. ${ }^{13}$ Secara fisiologis, janin bersifat steril dari mikroorganisme selama dalam kandungan. Namun, terjadi perubahan besar pada komposisi mikroflora usus pada awal kehidupan. Dalam kurun waktu beberapa jam setelah lahir, saluran cerna bayi mulai dikolonisasi oleh bakteri dan kolonisasi tersebut akan berubah sesuai dengan usia bayi yang bertambah. ${ }^{12-14}$

Kami mendapatkan jumlah koloni Bifidobacterium pada bayi yang lahir secara pervaginam lebih tinggi daripada seksio sesarea. Hal tersebut sesuai dengan penelitian di Padang yang mendapatkan bayi yang lahir pervaginam mempunyai jumlah kolonisasi Bifidobacterium yang lebih tinggi dibandingkan secara seksio sesarea. ${ }^{15}$

Kami mendapatkan jumlah koloni Lactobacillus yang tidak berbeda pada persalinan pervaginam dan seksio sesarea. Hal tersebut bertentangan dengan hasil penelitian sebelumnya yang mendapatkan kolonisasi
Lactobacillus yang tinggi pada bayi yang lahir secara pervaginam dibandingkan dengan seksio sesarea. ${ }^{3,11,16}$ Dalam penelitiannya di 7 rumah sakit di Cina, Yang $\mathrm{dkk}^{14}$ melaporkan koloni Lactobacillus pada bayi yang lahir pervaginam sangat berkurang. Hal tersebut berhubungan kejadian bacterial vaginalis yang tinggi pada ibu bersalin lahir pervaginam berkurang.

Kolonisasi mikrofkora usus pada bayi baru lahir dipengaruhi oleh diet bayi (air susu ibu (ASI), formula), jenis persalinan, usia gestasi, terapi antibiotik, satus kesehatan ibu, dan perawatan rumah sakit. ${ }^{4}$ Sebagaimana telah diketahui, ASI mengandung Lactobacillus dan Bifidobacterium. ${ }^{13}$ Hasil kolonisasi Lactobacillus yang tinggi pada seksio sesarea mungkin disebabkan pemberian ASI sebelum pengambilan sampel

Hasil penelitian kami mendapatkan jumlah koloni Clostridium pada persalinan pervaginam dan seksio sesarea tidak berbeda bermakna. Hasil tersebut berbeda dengan penelitian sebelumnya yang mendapatkan prevalensi dan hitung Clostridium yang tinggi pada bayi lahir secara seksio. ${ }^{17-19}$

Hasil koloni Clostridium yang rendah pada seksio sesarea mungkin disebabkan adanya pemberian antibiotik pada ibu sebelumnya, dan bakteriosin yang dapat menghambat pertumbuhan Clostridium. Bakteriosin ini diproduksi oleh Bifidobacterium, Lactobacillus, dan Ruminococcus. Ruminococcus ini banyak terdapat dalam ASI. ${ }^{13,20}$

Keterbatasan penelitian kami adalah tidak diperhitungkan faktor lain yang memengaruhi mikroflora ini, seperti pemberian ASI, susu formula, dan pemberian antibiotik pada ibu.

Kami menyimpulkan bahwa persalinan pervaginam kolonisasi mikroflora Bifidobacterium lebih tinggi dibandingkan dengan seksio sesarea. Tidak terdapat perbedaan kolonisasi mikroflora Lactobacillus dan Clostridium pada persalinan pervaginam dan seksio sesarea. Diperlukan penelitian lebih lanjut dengan memperhitungkan faktor lain yang memengaruhi mikroflora usus pada bayi baru lahir. 


\section{Daftar pustaka}

1. Guarner F, Malagelada JR. Gut flora in health and disease. Lancet 2003;361:512-9

2. Rastall RA. Bacteria in the gut: friends and foes and how to alter the balance. J Nutr 2004;134:2022-6

3. Evdokia K, Mitsou, Kirtzalidou E, Oikonomou I, Liosis G, Kyriacou A. Fecal microflora of Greek healthy neonates. Anaerob 2008;14:94-101.

4. Penders J, Thijs C, Vink C, Stelma F, Snijders B, Kumelling I, dkk. Factors influencing the composition of the intestinal microbiota in early infancy. Pediatrics 2006;118:511-21

5. Hutt P, Shchepetova J, Loivukene K, Kullisaar T, Mikelsaar M. Antagonistic activity of probiotic lactobacilli and bifidobacteria against entero and uropatogens. J Appl Microbiol 2006:100:1324-32

6. Reuter G. The Lactobacillus and Bifidobacterium microflora of the human intestine: composition and succession. Microbiol 2001;2:43-53.

7. Reyed RM. The role of Bifidobacteria in health. J Med Sci 2007;1:14-24.

8. Karlsson H, Hessle C, Rudin A. Innate immune responses ofhuman neonatal cells to bacteria from the normal gastrointestinalflora. Infect immun 2002;70:6688-96.

9. Dinkci N, Unal G, Akalin S, Gonc S. The importance of probiotics in pediatrics. J Pakistan Nutr 2006;6:608-11.

10. Satokari RM, Vaughan EE, Akkermans AL, Saarela M, Vos WM. Bifidobacterial diversity in human feces detected by genus specific PCR and denaturing gradient gel electrophoresis. Appl Environ Microbial 2005;67:504.

11. Dominguez-Bello MG, Costello, EK, Contreras M, Magris M, Hidalgo G, Fierer N, Knight R. Delivery mode shapes the acquisition and structure of initial microbiota across multiple body habitats in newborns. Proc Natl Acad Sci USA 2010;107:11971-5
12. Yoshioka H, Iseki K, Fujita K. Development and differences of intestinal flora in neonatal period in breast-fed and bottle-fed infants. Pediatrics 1983;72:317-21.

13. Martin R, Soberon N, Vaneechoutte M, Florez AB, Vasquez F, Suarez JE. Characterization of indigenous vaginal Lactobacilli from health women as probiotic candidates. Int Microbiol 2008;11:261-6.

14. Yang XL, Yang HX, Duan T, He J, Sum LZ, Yu TH. Vaginal Microflora and relevant factors in puerperium. Chin Med J 2009:Jul;447:496-9.

15. Irwanto EL, Yusrawati I, Jurnalis YD, Rasyid R, Machmud R. Effect of spontaneous delivery and elective caesarean section on number of Bifidobacterium colony in newborns. Obstet Gynecol 2011 35: 49-52

16. Chen J, Cai W, Feng Y. Development of intestinal Bifidobacteria and Lactobacilli in breast-fed neonates. Clin Nutr 2007 Oct;26:559-66.

17. Penders J, Thijs C, Vink C, Stelma F, Snijders B, Kumelling I, dkk. Quantification of Bifidobacterium spp. Eschericia coli and Clostridium difficile in faecal samples of breastfed and formula-fedinfants by real-time PCR. FEMS Microbiol 2005;243:141-7.

18. Alderberth I, Lindberg E, Abery N, Iriesselmar B, SaaIrnati $\mathrm{R}$, Strannergard IL, dkk. Reduced enterobacterial and increased staphylococcal colonization of the infantile bowel: an effect of hygienic lifestyle. Pediatr Res 2005;59:96101.

19. Bennet R, North CE. Development of the fecal anaerobic microflora after cesarean section and treatment with antibiotic in new born infants. Infect 2000;15:332-6.

20. Lozo J, Vukasinovic M, Strahinic I, Topisirovic L. Characterization andantimicrobial activity of bacteriocin 217 produced by natural isolate lactobacillus paracasei subsp. Paracasei BGBUK2-16. J Food Prot 2004;67:2727-34. 